\title{
Using indirect calorimetry in place of fixed energy prescription was feasible and energy targets were more closely met: do not forget an important limitation
}

\author{
Patrick M. Honore*, Leonel Barreto Gutierrez, Luc Kugener, Sebastien Redant, Rachid Attou, Andrea Gallerani and \\ David De Bels
}

We read with great interest the recent article by Lambell et al. discussing nutrition therapy in critically ill patients and the role of indirect calorimetry (IC) [1]. Indirect calorimetry allows for the measurement of $\mathrm{VO} 2$ and $\mathrm{VCO} 2$ through the ventilator and is the gold standard method for measuring resting energy expenditure (REE) in critical illness when ideal test conditions are implemented [1]. Both the European (ESPEN) and American (ASPEN/ SCCM) clinical practice guidelines recommend the use of IC to measure energy expenditure [1]. At this time, there are only three randomized controlled trials (RCTs) comparing IC with formulae ( $25 \mathrm{kcal} / \mathrm{kg} /$ day) [1]. In all three RCTs, indirect calorimetry was feasible and energy targets were more closely met when using IC in place of fixed energy prescription [1]. While supporting the use of IC in some settings, we believe it is important to warn clinicians about a limitation of the technique, particularly when patients are under continuous renal replacement therapy (CRRT) [2]. Fifty percent of the critically ill septic and non-septic population develop acute kidney injury, and 25\% require renal replacement therapy (RRT) [3]. Patients undergoing CRRT lose a substantial amount of $\mathrm{CO}^{2}$, in gas form and as bicarbonate, in the effluent, making IC unreliable [4]. This is also true for IC performed in patients receiving extracorporeal membrane oxygen (ECMO), unless a mathematical correction is applied [5]. It is important that clinicians are aware not only of the indications of IC, but also of the limitations.

\section{Authors' response}

Response to the letter to the editor: "Using indirect calorimetry in place of fixed energy prescription was feasible and energy targets were more closely met: do not forget an important limitation"

Kate J Lambell, Oana A Tatucu-Babet and Emma J Ridley

We thank Professor Honore and colleagues for their interest in our paper "Nutrition therapy in critically illness: a review of the literature for clinicians" [1]. In the review, we discuss the clinical guideline recommendations and evidence supporting the use of indirect

\footnotetext{
This comment refers to the article available at https://doi.org/10.1186/ s13054-020-2739-4.

* Correspondence: Patrick.Honore@CHU-Brugmann.be

ICU Department, Centre Hospitalier Universitaire Brugmann, Place Van Gehuchtenplein, 4, 1020 Brussels, Belgium
}

calorimetry (IC) to measure energy expenditure and guide energy delivery [1]. We highlight that energy targets are met more closely with the use of IC than predictive equations, but there are limited studies reporting a benefit on clinical outcomes when IC is used. To further investigate the impact of using IC on clinical outcomes, we recently published a systematic review, evaluating if energy delivery guided by IC impacted hospital mortality and other important outcomes compared to when predictive equations were used [6]. We

(c) The Author(s). 2020 Open Access This article is licensed under a Creative Commons Attribution 4.0 International License, which permits use, sharing, adaptation, distribution and reproduction in any medium or format, as long as you give appropriate credit to the original author(s) and the source, provide a link to the Creative Commons licence, and indicate if changes were made. The images or other third party material in this article are included in the article's Creative Commons licence, unless indicated otherwise in a credit line to the material. If material is not included in the article's Creative Commons licence and your intended use is not permitted by statutory regulation or exceeds the permitted use, you will need to obtain permission directly from the copyright holder. To view a copy of this licence, visit http://creativecommons.org/licenses/by/4.0/ The Creative Commons Public Domain Dedication waiver (http://creativecommons.org/publicdomain/zero/1.0/) applies to the data made available in this article, unless otherwise stated in a credit line to the data. 
identified four randomized control trials and found no differences in intensive care unit mortality and hospital length of stay between groups [6]. However, the duration of mechanical ventilation was increased when IC guided energy delivery [6]. Further investigation is required to understand how the use of IC to guide energy delivery impacts clinical and functional outcomes in critically ill adults, particularly across different phases of illness. And, as pointed out by Professor Honore and colleagues, there are limitations in some populations.

Importantly, Professor Honore and colleagues highlight that the use of IC may not be reliable during continuous renal replacement therapy (CRRT) andextracorporeal membrane oxygenation (ECMO) due to the removal of $\mathrm{CO}_{2}$ by the membrane in CRRT and inability to capture $\mathrm{O}_{2}$ uptake and $\mathrm{CO}_{2}$ removal during ECMO. To ensure accurate determination of energy expenditure, all limitations to IC must be considered, and we refer readers to a comprehensive review outlining technical factors affecting IC measurement [7]. Of interest, investigation to try and understand the influence of CRRT on $\mathrm{VCO}_{2}, \mathrm{VO}_{2}$, and energy expenditure (by IC) has recently been published [8]. In a small observational study of 10 critically ill patients receiving CRRT, $\mathrm{CO}_{2}$ removal by CRRT led to a minimal change of $3 \%$ in measured energy expenditure, a difference that is not considered clinically important [8]. In addition to the study mentioned by the authors, another study has been completed [9], and another is underway to develop methods to accurately measure energy expenditure in patients receiving ECMO ( $A C T R$ N12619000760178). These are important studies investigating methods to measure energy expenditure using IC in nutritionally vulnerable populations where limitations to traditional IC exist.

\section{Abbreviations}

IC: Indirect calorimetry; REE: Resting energy expenditure; RCTs: Randomized controlled trials; RRT: Renal replacement therapy; CRRT: Continuous renal replacement therapy

\section{Acknowledgements}

We would like to thank Dr. Melissa Jackson for critical review of the manuscript.

\section{Authors' contributions}

$\mathrm{PMH}, \mathrm{SR}$, and DDB designed the paper. All authors participated in drafting and reviewing. All authors read and approved the final version of the manuscript.

\section{Funding}

None.

Availability of data and materials

Not applicable.

Ethics approval and consent to participate

Not applicable.

Consent for publication

Not applicable.

\section{Competing interests}

The authors declare to have no competing interests.

Received: 19 May 2020 Accepted: 8 June 2020

Published online: 19 June 2020

\section{References}

1. Lambell KJ, Tatucu-Babet OA, Chapple LA, Gantner DJ, Ridley E. Nutrition therapy in critical illness: a review of the literature for clinicians. Crit Care. 2020;24:35 https://doi.org/10.1186/s13054-020-2739-4.

2. Jonckheer J, Spapen H, Malbrain MLNG, Oschima T, De Waele E. Energy expenditure and caloric targets during continuous renal replacement therapy under regional citrate anticoagulation. A viewpoint. Clin Nutr. 2020; 39(2):353-7. https://doi.org/10.1016/j.clnu.2019.02.034 Epub 2019 Feb 23. Review.

3. Peters $E$, Antonelli M, Wittebole $X$, Nanchal R, François B, Sakr $Y$, et al. A worldwide multicentre evaluation of the influence of deterioration or improvement of acute kidney injury on clinical outcome in critically ill patients with and without sepsis at ICU admission: results from The Intensive Care Over Nations audit. Crit Care. 2018;22(1):188 https://doi.org/ 10.1186/s13054-018-2112-z.

4. Jonckheer J, Spapen H, Debain A, Demol J, Diltoer M, Costa O, Lanckmans K, Oshima T, Honoré PM, Malbrain M, De Waele E. Correction to: CO2 and O2 removal during continuous veno-venous hemofiltration: a pilot study. BMC Nephrol. 2019;20(1):312. https://doi.org/10.1186/s12882-019-1480-1.

5. De Waele E, Jonckheer J, Pen JJ, Demol J, Staessens K, Puis L, La Meir M, Honoré PM, Malbrain MLNG, Spapen HD. Energy expenditure of patients on ECMO: a prospective pilot study. Acta Anaesthesiol Scand. 2019;63(3):360-4. https://doi.org/10.1111/aas.13287 Epub 2018 Nov 6.

6. Tatucu-Babet OA, Fetterplace K, Lambell K, Miller E, Deane AM, Ridley EJ. Is energy delivery guided by indirect calorimetry associated with improved clinical outcomes in critically ill patients? A systematic review and metaanalysis. Nutr Metab Insights. 2020. https://doi.org/10.1177/ 1178638820903295.

7. Schlein KM, Coulter SP. Best practices for determining resting energy expenditure in critically ill adults. Nutr Clin Pract. 2014;29(1):44-55.

8. Jonckheer J, Demol J, Lanckmans K, Malbrain ML, Spapen H, De Waele E. Metabolic consequences of continuous veno-venous hemofiltration on indirect calorimetry. Clin Nutr. 2020. https://doi.org/10.1016/j.clnu.2020.04. 017.

9. Wollersheim T, Frank S, Müller MC, Skrypnikov V, Carbon NM, Pickerodt PA, Spies C, Mai K, Spranger J, Weber-Carstens S. Measuring Energy Expenditure in extracorporeal lung support Patients (MEEP)-protocol, feasibility and pilot trial. Clin Nutr. 2018;37(1):301-7.

\section{Publisher's Note}

Springer Nature remains neutral with regard to jurisdictional claims in published maps and institutional affiliations. 